\title{
THE CONSTRUCTION OF INDONESIAN MUSLIMS AND ISLAM IN AUSTRALIAN NEWSPAPERS: A CORPUS-ASSISTED CRITICAL DISCOURSE ANALYSIS
}

\author{
Muchamad Sholakhuddin Al Fajri
}

\begin{abstract}
This study aims to investigate the discursive representation of Indonesian Muslims in the Australian press by employing a methodological synergy of corpus linguistics and critical discourse analysis. It analyses two different corpora of Australian newspapers from two different periods (2002-2006 and 2012-2016). Keyword and collocation analyses were used to reveal recurrent patterns or dominant discourses of Indonesian Muslims. Concordances were then investigated to analyse the data more qualitatively. The findings suggest that dominant discourses around Indonesian Muslims in the Australian newspapers are related to terrorism and extremism and they have not undergone a dramatic shift over the last 15 years. It then can be argued that the media representations of Muslims in Indonesia, a country that is not involved in major conflict and wars, are still primarily negative. While the Australian newspapers canonically portray Indonesian Muslims as moderate, the frequencies for moderate belief words are lower than strong belief words and the term is mainly used in the discussion of terrorism and extremism. Also, a qualitative analysis of the term moderate suggests that in few cases it carries implications that being tolerant of other religions is not a default character of a majority-Muslim country.
\end{abstract}

\section{Keywords}

corpus linguistics, critical discourse analysis, Muslim representations, news discourse, Indonesian Muslims

\section{Introduction}

Studies on the representation of Islam and Muslims in western newspapers have been well-established. Several researchers have conducted analyses on the construction of Muslims and Islam in the media by applying a variety of techniques and approaches (e.g. Baker et al. 2013a, Brown \& Richards 2016). Their results largely point out that Islam and Muslims are depicted more negatively through strong associations with terrorism and violence. Nevertheless, these previous studies have a tendency to examine media constructions of Muslims as a homogenous community. That is to say that very limited work focuses on the discursive representation of Muslims from a specific denomination, region or country. Western media coverage itself seems to focus more on Muslim countries that are in conflict or war. Richardson (2004) points out that in the British press, 
Indonesia, which has the largest Muslim population, is often backgrounded and Muslim countries which are foregrounded are those that are seen as dangerous and problematic, such as Afghanistan and Iraq. This argument is congruent with Baker et al.'s (2013a: 141) finding that the British press tends to overlook Muslim countries that have the largest Muslim populations, such as Indonesia, and focuses more on countries in which there are smaller concentrations of them, such as Iraq, Iran and Pakistan. Indonesia itself is a democratic nation which is different from most Muslim countries. However, Muslims in Indonesia have also attracted international attention particularly from the Australian government since the declaration of the "war on terror". The Indonesian government opposed U.S. military action and Australia's military involvement in Iraq and Afghanistan (Smith 2003) and a large majority of Indonesian Muslims saw the US attacks on Afghanistan as "morally unjustified" (Emmerson 2002: 121). Also, in 2002, a year after the declaration, Indonesian terrorists committed a suicide bombing (known as Bali bombing) that killed more than 80 Australian citizens who were on vacation in Bali. The so-called "Jemaah Islamiyah", the terrorist group convicted for the bombing, was also linked to al-Qaeda, the terrorist organisation that took responsibility for the 9/11 attack. The Australia's relations with Indonesia came under greater stress after Howard's (Prime Minister of Australia from 1996 to 2007) statement in 2002 about Australian right to take pre-emptive actions against Muslim terrorists in neighbouring countries (Mackie 2015). Thus, based on these political and historical contexts, it seems essential to study how Indonesian Muslims are represented in Australian newspapers and whether they have different portrayals from Muslims in general.

In addition, since discourse is not static (Baker 2006), it is significant to investigate whether the representation of Indonesian Muslims in the Australian press has undergone a change over the last fifteen years. Therefore, I decided to look at two time periods: 2002-2006, when the first Bali bombing and major terrorist attacks (e.g. the Australian embassy bombing in 2004 and second Bali bombing in 2005) occurred, and 2012-2016, a decade after the first Bali bombing.

\section{News discourse}

News discourse plays a significant role in society as it has the ability to influence people's opinions of an event or issue and a group of people. As Bednarek and Caple (2012: 6) point out, news discourse and media can exert enormous influence on governments and major institutions, and they also have an ability to form our ideas and behaviours. Similarly, Caldas-Coulthard (2003: 273) argues that news has a social, an educational and a political role, in which people attempt to comprehend and describe how events reported in the 
media are relevant to their society and lives as a whole. News, therefore, does not only passively function as a source of information but also as a tool that can potentially influence us and our society.

However, since news is "a socially and ideologically controlled set of constructive strategies" (van Dijk 1988: 28) or socially and ideologically constructed (Fowler 1991), the representation of events or social groups in the media is not a neutral or objective reflection of social reality. There are always different ways of reporting the same event. Differences in utterances can bring distinct ideology and therefore differences in representation (Fowler 1991), giving rise to specific interpretational patterns of understanding of social issues, relations, and identities (Habermas 1996). For these reasons, news discourse is of interest to critical analysts and by studying representations of a group of people such as Indonesian Muslims in the press, we might obtain insights into mainstream ideological stances within a society.

\section{Islam and Muslim representations in news media}

Richardson (2004) applies CDA approaches to investigate the discursive representation of Islam and Muslims in British broadsheet newspapers over a four-month period, from October 1997 to January 1998. He finds that British broadsheet newspapers divide and reject Muslims via three processes: separation, differentiation and negativisation, and predominantly use four prejudicial strategies to derogate Muslims: as a military threat, as an extremist threat, as a threat to democratic stability, and as a threat to gender equality or a social threat.

Similarly, in Australian contexts, Kabir (2006: 326), who analysed news articles published in Australian broadsheet newspapers from 2001 to 2005, concludes that the media representation of Islam and Muslims focuses more on Islamic militants and does not provide balanced coverage. His study also suggests that dress, religious practices and customs of Muslims are frequently constructed as having strong associations with terrorist activities.

Recently, corpus approaches to discourse analysis have also been employed to research Islam and Muslim representations in the media. For instance, Baker et al. (2013a, 2013b) examine a 143-million-word corpus of British newspaper articles published between 1998 and 2009. Their study suggests that Muslims are typically constructed as homogenous and different from 'The West', easily offended, alienated and connected to conflict.

The review of these previous studies on Muslim representations serves to demonstrate that there is a pattern of negative representation of Islam and Muslims in the press. It also shows that in order to obtain an impression of a general picture, a larger number of articles that cover longer time periods have 
been employed in the last two previous studies. Following Baker et al. (2013a, $2013 \mathrm{~b}$ ), this present study also employed corpus linguistic approaches to critical discourse analysis to investigate media representations of Muslims, but it focused on Indonesian Muslims, instead of Muslims in general.

\section{Corpus construction}

The news texts were collated from the online searchable database of newspaper articles, Nexis UK. This online software can enable the researcher to look for news texts containing specific search terms or certain words, and the searches can be restricted to particular newspapers and time spans. Identifying accurate search terms is essential to ensure that every single article referring to Indonesian Muslims is included in the corpora. Initially, I used the search terms as follows:

Indonesia* Muslim* OR Indonesia* Moslem* OR Muslim* in Indonesia OR Moslem* in Indonesia OR Muslim* from Indonesia OR Moslem* from Indonesia OR Indonesia* Islam OR Islam in Indonesia ${ }^{1}$

An asterisk at the end of a word acts as a wildcard, meaning that Indonesia* refers to Indonesia and Indonesians. These search terms, nevertheless, missed articles where Indonesian Muslims were referred to just as 'Muslims'. For example,

More than 90 percent of Indonesians describe themselves as Muslim, but the vast majority practise a moderate form of the faith. (The Daily Mail, 15 August 2016)

In these examples, the articles talk about Indonesian Muslims, but they are only referred to as 'Muslims' in the same sentence with the word 'Indonesia'. Therefore, in order to fully capture every reference to Indonesian Muslims, the final search terms employed were as follows:

Indonesian* OR Indonesia Within the Same Sentence Muslim* OR Moslem* OR Islam

Moreover, in order to obtain a large variety of voices in the Australian press, I selected all national and regional newspapers. However, with this wide range of newspapers, the same article may appear multiple times in the Nexis database, which may make frequencies of certain words being skewed, with overrepresentation of certain patterns (Baker 2014b: 110). Therefore, since the Nexis can be instructed to exclude any duplicate articles that have a high or moderate similarity to each other, I set the duplicate filter on "moderate similarity" in order 
to achieve the most accurate data set. The time span is set to a four-year span from 2002 to 2006 and from 2012 to 2016 . The details of the corpora can be seen in Table 1.

\begin{tabular}{|l|c|c|}
\hline Corpora & Number of articles & Number of words \\
\hline $\begin{array}{l}\text { 2002-2006 Australian corpus } \\
\text { (AUS0206) }\end{array}$ & 3,863 & $2,694,414$ \\
\hline $\begin{array}{l}\text { 2012-2016 Australian corpus } \\
\text { (AUS1216) }\end{array}$ & 1,164 & 913,663 \\
\hline
\end{tabular}

Table 1: Details of the corpora

Although the two corpora have the same time span, there is a considerable disparity between the number of articles and words in the former corpora and the latter. The higher number of articles in the 2002-2006 corpora might be because the topic about Indonesian Muslims was considered more 'newsworthy' in that period. The news value of 'negativity' (Golding \& Elliott 1979) may play a part in this substantial difference. This will be described in more detail in the analysis section.

\section{Methodology}

In order to answer the research questions, three corpus analytical tools were employed: keyword, concordance and collocation, and AntConc 3.4.4 software (Anthony 2018) was used to conduct all the three analyses. In the first step, I identified keywords in the corpus. Keywords are words which are significantly more recurrent than expected in one corpus when compared with another corpus (McEnery et al. 2015). Examining keywords can reveal lexical items that may be not highly frequent but are statistically prominent in some way (Baker \& McEnery 2015). This technique is canonically applied in comparative or diachronic studies to spot distinct features in each corpus under analysis, which may show consistent, resistant or changing discourses.

The keyword analysis was conducted by comparing the AUS0206 corpus against the AUS1216 corpus and vice versa by using the log-likelihood measure. Following the keywords analysis, I investigated collocates of a number of words which seem directly related to the representation of Indonesian Muslims. Collocates are words that take place near or next to each other more often than would be anticipated if all words in a corpus are randomly ordered (Baker 2016). Examining collocates can lead to the concepts of 'semantic preference' 
(Louw 1993) and 'discourse prosody' (Stubbs 2007), which are of interest to critical discourse analysts.

In doing the collocation analysis, a span of five words on either side of the search term was used and collocates were calculated by Mutual Information (MI) score, which suggests the strength of the collocation (Baker 2016: 142) or measures the strength of the 'collocational bond' (Mautner 2007: 57). As suggested by Hunston (2002: 71), in order to be taken as significant, collocates need to have an MI score of at least 3. However, since MI can be likely to give priority to relatively low frequency words, a collocational pair that occurs less than five times was excluded.

It should be noted, however, that keywords and collocates were also examined via concordance analysis. This is where I applied some CDA approaches to achieve better interpretations of concordance lists and full news texts. I employed the Discourse-Historical Approach (DHA) to CDA (Wodak $\&$ Meyer 2016) to investigate how the predication strategies through discursive devices were applied to depict Indonesian Muslims. The DHA is interdisciplinary analysis which combines various approaches and empirical data. It elaborates five types of discursive strategies or intentional plan of practice implemented to obtain a certain socio-political or linguistic purpose, including nomination, predication, argumentation, perspectivization and mitigation (Wodak \& Meyer 2016). However, for this study, I only exercised predication strategy which aimed at giving social actors, objects or events evaluative attributions of negative or positive traits through some linguistic devices (e.g. in the form of explicit predicates, adjectives, collocations and conjunctional clauses). Legitimation framework proposed by van Leeuwen (2007) was also used to identify how journalists legitimated their claim. Moreover, the analysis was also complemented by CDA's commitment to investigate social context (van Dijk 1988). In other words, I also took into account a wider socio-political context outside the corpus, such as people's attitudes towards the use of particular terms, a fuller understanding of the term's significance, and information about who is quoted and cited by the newspaper. Considering these extra linguistic factors may help interpret the findings better and explain why such discourses occur, thus revealing the dialectical relationship between texts, discourse and social practices.

\section{Findings and discussion}

\subsection{Keywords}

Keywords of each corpus were identified by means of comparing the 2002-2006 corpus against 2012-2016 corpus (AUS0206 vs. AUS1216). Because 
of limited space, only the first 100 strongest keywords from each comparison were taken into account. Keywords were then categorised thematically by using quick concordance analyses in order to decide which group they best belonged to. Table 2 shows lists of keywords for the Australian newspapers, excluding function words and politician names which for the purpose of this study seem not to be fruitful.

\begin{tabular}{|c|c|c|}
\hline Category & AUS0206 & AUS1216 \\
\hline Terror/extremism & $\begin{array}{l}\text { Bashir, bombing, bombings, } \\
\text { terrorist, Bakar, bin, Hambali, } \\
\text { Laden, Amrozi, bomb, terrorism, } \\
\text { Al, azahari, abu, Osama, } \\
\text { bombers, terrorists, suicide, Qa, } \\
\text { ida, Samudra, Terror, roche, } \\
\text { Husin, Ghozi. }\end{array}$ & Jihadists \\
\hline Terrorist groups & $\begin{array}{l}\text { JI, Qaeda, Jemaah, Islamiah, } \\
\text { Islamiyah, Laskar, Faruq }\end{array}$ & ISIL, ISIS, Nusra, JAT \\
\hline Places/nationalities & $\begin{array}{l}\text { Bali, Iraq, US, embassy, Timor, } \\
\text { Singapore, Marriot, East, } \\
\text { Philippines, Maluku, Papua, } \\
\text { Afghanistan, Aceh, Indonesian, } \\
\text { Ambon }\end{array}$ & $\begin{array}{l}\text { Syria, Rohingya, Myanmar, } \\
\text { Syrian, China, Bendigo, } \\
\text { Egypt, Baghdadi, Here, Paris, } \\
\text { Nusakambangan, Rohingyas, } \\
\text { Bangladesh, Chinese }\end{array}$ \\
\hline Conflict & $\begin{array}{l}\text { war, troops, weapons, attack, } \\
\text { blast, blasts, attacks }\end{array}$ & \\
\hline Crime & suspects, arrest, accused & smugglers \\
\hline Organization & ASIO, UN & BNPT \\
\hline $\begin{array}{l}\text { Religious concepts/ } \\
\text { groups }\end{array}$ & Cleric & $\begin{array}{l}\text { Halal, Sunni, Caliphate, } \\
\text { brotherhood, Tahrir, Shia, } \\
\text { Hizbut, Gafatar, Pageant }\end{array}$ \\
\hline Other concepts & $\begin{array}{l}\text { evidence, network, targets, } \\
\text { tsunami, security, documents, } \\
\text { intelligence, links, involvement, } \\
\text { chief, leader, explosives, trials }\end{array}$ & $\begin{array}{l}\text { boats, state, cattle, asylum, } \\
\text { beef, blasphemy, boat, } \\
\text { seekers, refugees, sea, utions, } \\
\text { deradicalization, food, } \\
\text { certification, online, seeker, } \\
\text { alcohol, clemency, beer, social, } \\
\text { live, refugee }\end{array}$ \\
\hline
\end{tabular}

Table 2: Lists of keywords 
Having eliminated those words, there are still too many keywords to choose from. Thus, I more focused on the analysis of keywords that occurred in articles in which Indonesian Muslims or Islam were central to news stories or that contributed directly to the construction of Indonesian Muslims.

\subsubsection{Terrorism}

From the keyword lists, it is noticeable that Australian newspapers in the 2002-2006 period focus more on events and people relating to sets of terrorist attacks that occurred in Indonesia (the Bali bombings, $2002 \& 2005$; the JW Marriott Hotel bombing, 2003; the Australian embassy bombing, 2004). The related keywords include terror, terrorists, bombing, bomber, Bali, Marriot, Embassy, suicide, Osama, Amrozi, Bashir, Baasyir, Samudra, Mukhlas, Jemaah, Islamiyah, $\mathrm{Al}$, and Qaeda. Indeed, the term terror ${ }^{* 1}$ occurs more frequently than the word Islam* and Muslim*, which are two of the query terms. The collocation analysis of all forms of the term terror in the former corpus suggests that they significantly collocate with the word Islamist, with an MI score of at least 8 . Additionally, a search of Islam* terror* produced 468 concordance lines in the AUS0206 corpus. This phrasing is highly more recurrent than the term Muslim* terror*, which occurs 62 times. Although it has been argued that the reason why the press more associate concepts related to terrorism with Islam* rather than Muslim* is to "depersonalise more unpleasant connotations" (Baker et al. 2013a: $255)$, it appears that such representation can bring more negative connotations since when we say Islam/ic/ist/ terror/ist/ists/ism, the violent actions seem emanate from or are taught by the religion so that it might be unsurprising if its adherents are violent. Such terms are used uncritically to construct negative stereotypes of Muslims. Only one citation in the AUS0206 corpus reports the resentment against the frequent application of those terms:

(2) Almost 90 per cent of Indonesia's 220 million people are Muslim, and many resent the daily use of phrases such as "Islamic terrorists", which they feel denigrate them and their religion. (Sydney Morning Herald, 25 September 2003)

However, it should be noted that Islamic, a general term that refers to something connected with Islam and its adherents, is not a strong collocate of terror*, compared to the word Islamist, which is more related to fundamentalism or extremist political ideology. To examine this differing pattern of use among the Australian media further, I looked at where the articles containing the two terms (Islamic terror ${ }^{*} \&$ Islamist terror ${ }^{*}$ ) were published. Nevertheless, there is no clear-cut pattern since both right- and left-wing newspapers used both terms in 
the relatively same number of articles. For example, The Australian (right-centre) published news articles containing Islamist terror* and Islamic terror* 18 and 20 times respectively, while The Age (left-centre) published articles containing Islamist terror* and Islamic terror* 10 and 8 times respectively.

The next keyword for the 2002-2006 corpus that is significant to be discussed is Jemaah Islamiah/Islamiyah, which refers to the name of an armed militant organisation established in 1993 in Indonesia and responsible for most bombings during the 2002-2006 period (Magouirk et al. 2008). The repeated occurrences of the term may also contribute to the construction of Indonesian Islam/Muslims as the Arabic term Jemaah Islamiyah, written also as Jemaah Islamiah, means "community of Muslims" or "Islamic community". Jemaah Islamiah/Islamiyah (JI) occurs 2,144 times in the AUS0206 corpus. A notable aspect of JI is that it contains a negative discourse prosody (Stubbs 2001: 65) of terrorism and extremism since it mainly collocates with words related to terror, such as terror, terrorist, terrorists, bomb and bombmaker, and with extreme beliefs, such as extremist, extremists, militant, militants, and radical. Additionally, it is also described as an illegal organisation (with collocates like outlawed and underground). The use of this term has been criticised by most Indonesian Muslims and Muslim leaders and has become part of the public debate (Pavlova 2007: 778). The Indonesian government, the police and the press in Indonesia also avoid mentioning the term. However, while the term is problematized, it is continuously and uncritically used in the former corpus and there are only six articles in the AUS0206 that report the criticism of its use:

There are probably thousands of "Jemaah Islamiyah" across Indonesia, nearly all informal and committed to peaceful religious activity. Thus, when Western leaders refer repeatedly to Jemaah Islamiyah, it is liable to be seen as a broader attack on Islam itself. (The Courier Mail, 20 October 2003)

Furthermore, the word linked is a collocate of JI and a keyword in the former corpus. It commonly occurs in clusters: al-Qaida linked, al-Qaeda linked, linked to al Qaeda and linked to al-Qaeda. By analysing concordance lines of these clusters, I found that they were predominantly used to associate JI with al-Qaeda, which might serve to indicate that they have the same ideology and thus sustain the negative representation of JI:

(4) Jakarta police and the US Embassy have warned of a high risk of seasonal terror attacks from the al-Qaida-linked Jemaah Islamiah. (Herald Sun, 25 December 2003) 
Also, an examination of 50 random concordance lines of linked suggests that 21 lines describe Abu Bakar Bashir/Baasyir as the spiritual leader of JI. A collocation analysis of Bashir, which is also a keyword, indicates that besides collocating with more negative words, such as firebrand, treason, militant, jail and jailed, it strongly collocates with cleric (647 times) and spiritual (233 times). When it collocates with cleric, it is mainly presented in the phrase Muslim cleric (515) and Islamic cleric (54). This therefore influences the representation of Muslim cleric and Islamic cleric. Muslim cleric itself significantly and frequently collocates with radical, militant, firebrand, treason, hardline, jailed and arrest.

It might be important to note that Bashir is referred to significantly more frequent than Amrozi, Samudra and Mukhlas, all of whom are convicted of coordinating and carrying out the 2002 Bali bombings. Thus, it may reveal that the Australian newspapers when reporting about the attackers of Bali bombings focus more on Bashir and foreground his status as a Muslim cleric, thus contributing to the negative representation of Indonesian Muslims. Additionally, among 50 random concordances of linked, three concordances represent Islamic schools as having links to JI and Bali bombers:

Mr Kalla was equally dismissive of the threats posed by the few Islamic boarding schools linked to JI, such as the Ngruki school in Solo, founded by extremist preacher Abu Bakar Bashir, on trial for terrorism. (The Australian, 15 November 2004)

In the AUS1216 corpus, a lot of keywords that belong to terrorism/extremism thematic group like terror, terrorism, Bashir, Jamaah Islamiah and bombings are absent. This may indicate a decline in the number of articles discussing terrorism topics. A close reading analysis of jihadists, the only terrorism-related word that becomes a keyword in the AUS1216, shows that of 50 random concordances, 30 occurrences of jihadists are in the discussion of terror attacks in Indonesia and the departure of some Indonesians to Syria or Iraq to join ISIS with additional stories about the past Bali bombings:

(6) Hard-line clerics do nothing to dissuade jihadists. The Javanese Islamic school that once taught Bali bombers Amrozi and Mukhlas is still running, and still inspiring students to take up jihad. (Sunday Times, 09 November 2014)

Indeed, the phrase Bali bomb* still occurs 342 times in the AUS1216. This suggests that although the Bali bombings happened more than a decade ago, they are still of interest to the Australian newspapers in the 2012-2016 period. As a means of analysing this further, I conducted a close investigation into 
50 random concordances in 50 different articles across newspapers containing the phrase Bali bombing/s in order to find out in what topics and contexts Bali bombing/s are mentioned. The results indicate that most articles (34) cite the Bali bombings when talking about issues related to terrorism, such as recent terror attacks in Indonesia, involvement of some Indonesian Muslims in ISIS, Indonesian police's success in arresting terrorist suspects and foiling terror plots, and Islamic schools' role in terrorism. For example,

(7) The last time Indonesia's radical Muslims were religiously endorsed to fight jihad overseas was in Afghanistan. They returned to Indonesia and orchestrated attacks including the Bali bombings, which killed 222 including 92 Australians, and the bombing of the Australian embassy. (Sydney Morning Herald, 20 January 2015)

Also, four articles describe the Bali bombings when reporting about the rise of radical Islam or Muslims, one of which indicates that the journalist applies a distancing technique to legitimate the claim, by attributing it to "expert authority" (van Leeuwen 2007: 94):

The man who led the post-Bali bombing terror crackdown has issued a chilling warning about radical Islam's unchecked growth across Indonesia. (The Courier Mail, 9 November 2014).

Other topics are related to Indonesia-Australia relations (5) and exclusive reports on JI, Bashir and some terrorists as a part of $10^{\text {th }}$ or $12^{\text {th }}$ anniversary of the Bali bombings (7).

\subsubsection{Blasphemy}

The word blasphemy is a keyword in the AUS1216, occurring 144 times. It strongly collocates with laws, but this connected phrase tends to be described as problematic and a source of social problems, especially in Muslim countries. Moreover, the word blasphemy largely refers to a blasphemy case against Jakarta's Governor, Basuki Tjahaja Purnama or Ahok, which are also keywords. This case is predominantly described as a test on religious tolerance and Indonesian pluralism and democracy, e.g.:

(9) The national upheaval over Gov. Basuki "Ahok" Tjahaja Purnama's alleged blasphemy has challenged Indonesia's reputation for practicing a moderate form of Islam, shaken the government and exposed religious and racial fault lines. (The Cairns Post, 14 December 2016) 
This example may suggest a positive construction of Indonesian Muslims as practicing a moderate form of Islam, but a closer study on the concordance lists in the corpus points out that most articles focus more on the danger of the growth of hardline Muslims in Indonesia while describing Indonesia as a tolerant Muslim country.

Also, when reporting a protest demanding prosecution of Ahok, the demonstrators are mostly labelled as hardline, hardliners, and Islamists:

(10) Besieged governor Basuki “Ahok” Tjahaja Purnama will stand trial for blasphemy next Tuesday, just over a week after a rally organised by hard-line Islamists demanding his arrest drew hundreds of thousands of Indonesian Muslims onto the streets. (The Australian, 6 December 2016)

In this case, although Indonesian Muslim leaders state that most of the protesters are not Muslim hardliners, they are still predominantly constructed as hardline Muslims, hardliners or Islamists in the newspapers. Also, only one article in the AUS1216 corpus cites the opinion of Indonesian Muslim leaders:

(11) Din Syamsuddin is the chairman of the advisory council of the Indonesian Council of Ulama (MUI), Indonesia's top Islamic scholarly body. [...] Din estimates 60 to 70 per cent of those who attended the December 2 rally were from the Muslim middle class and not hardliners. (The Age, 24 December 2016)

This may suggest that the categorisation of Muslims as extreme, hardline, or moderate in the news media is sometimes not really factual and depends on the newspaper political interests. In such a way, looking for information beyond the concordances like who is quoted and cited by the newspaper may assist to obtain the perspectivization or the overall stance of an article (Baker 2014a, Reisigl \& Wodak 2001).

\subsection{Collocation}

In this section, I only studied the search term Muslim since it is the most frequent one and seems to be highly relevant to the representation of Indonesian Islam and Muslims. I focused on the 50 strongest collocates of each period and concentrated more on those that revealed dominant representations of Indonesian Muslims. Table 3 demonstrates the top 50 Muslim collocates after being grouped on the basis of the discourse prosody (Stubbs 2007) that they express. It is noticeable that Muslim saliently and frequently collocates with words denoting strength of frequency (predominantly, overwhelmingly) and a proportion of population (majority, populous, largest, biggest) in all corpora. These words 
mostly occur together with the collocate nation or country in clusters like most populous Muslim nation, largest Muslim country, Muslim majority nation and predominantly Muslim country, describing Indonesia as a country which has the largest Muslim populations.

Concordance analyses of these collocates in the 2002-2006 corpus reveal that such phrases tend to occur in negative descriptions, particularly terrorism and extremism, while in the 2012-2016 corpus they tend to have positive representations:

(12) A devastating blast at the Marriott Hotel in Jakarta two days before the bomber's sentencing has reinforced a suspicion that Islamic militancy in the world's most populous Muslim country is taking on new, more dangerous dimensions. (Illawarra Mercury, 12 August 2003)

(13) While both [Indonesian and Malaysia] have large Muslim majorities, they have cultivated a reputation for tolerance of the other religions that make up their complex social and ethnic fabric. (Australian Financial Review, 23 January 2015)

This difference seems to be mostly affected by the considerable occurrences of keywords related to terrorism and conflict in the 2002-2006 period. It should be noted, nevertheless, that a few instances indicating positive representations may be rather problematic. For example, while Example 13 largely suggests positive portrayals of Indonesian Muslims, the use of the conjunction while may also imply that being tolerant towards other religions is not a default characteristics of a Muslim-majority country since while in this case carries the additional "conventional implicature" (Grice 1975: 44-45), suggesting that the two propositions have contrasting truth values; "that is, the assertion of the second proposition is surprising, in view of the first" (Leech 2014: 74). 


\begin{tabular}{|c|c|c|}
\hline Collocates & AUS0206 & AUS1216 \\
\hline Degree of belief & $\begin{array}{l}\text { firebrand, moderate, pious, } \\
\text { devout, hardliners }\end{array}$ & hardliners, devout, moderate \\
\hline $\begin{array}{l}\text { Population/ } \\
\text { frequency }\end{array}$ & $\begin{array}{l}\text { populous, populations, } \\
\text { populated, majority, largest, } \\
\text { population, overwhelmingly, } \\
\text { majorities, nation }\end{array}$ & $\begin{array}{l}\text { populous, populations, predominantly, } \\
\text { worlds, populated, majority, largest, } \\
\text { population, societies, overwhelmingly, } \\
\text { biggest, nation }\end{array}$ \\
\hline $\begin{array}{l}\text { Conflict/ } \\
\text { terrorism/crime }\end{array}$ & $\begin{array}{l}\text { pretended, razed, fake, oppress, } \\
\text { upsetting, Baasyir, Bakar, Abu, } \\
\text { mobs, gangs, inflaming, warring }\end{array}$ & $\begin{array}{l}\text { spooked, insurgency, separatist, } \\
\text { persecuted, sleeper, Islamism, } \\
\text { minority }\end{array}$ \\
\hline Clothes & $\begin{array}{l}\text { garb, headdress, headscarves, } \\
\text { burqa. }\end{array}$ & hijab \\
\hline $\begin{array}{l}\text { Name of Islamic } \\
\text { organisation/ } \\
\text { collective }\end{array}$ & $\begin{array}{l}\text { brotherhood, Nahdlatul Ulama, } \\
\text { communities }\end{array}$ & $\begin{array}{l}\text { brotherhood, Nahdlatul, Ulama, } \\
\text { communities, community }\end{array}$ \\
\hline Religion/belief & $\begin{array}{l}\text { cleric, clerics, animist, sect, } \\
\text { Ulemas, fasting, Buddhist, } \\
\text { Shi'ite }\end{array}$ & $\begin{array}{l}\text { saints, clerical, sect, Ulema, } \\
\text { pilgrimage, Ahmadiyya, convert }\end{array}$ \\
\hline Differentiation & alienating & alienate \\
\hline $\begin{array}{l}\text { Education/ } \\
\text { movement }\end{array}$ & & scholar, feminists, decent, scholars \\
\hline Others & $\begin{array}{l}\text { envoys, devoutly, Ziauddin, } \\
\text { staunchly, overtly, } \\
\text { neighbourhoods, Keysar }\end{array}$ & $\begin{array}{l}\text { unequivocal, typically, causing, styled, } \\
\text { identify, Mindanao, Lebanese, graves, } \\
\text { charity, democracies }\end{array}$ \\
\hline
\end{tabular}

Table 3: Fifty strongest collocates of Muslim in the Australian newspapers

The other typical collocates of Muslim are words indicating types or levels of belief (devout, moderate, extremists, fundamentalists, hardliners). Before investigating these words in more details, it is essential to note that among the 50 strongest collocates, moderate is the most common type of belief, but when considering all collocates of Muslim which have an MI score of at least 3, Muslim still more frequently collocates with strong belief words (e.g. militants, radicals, extremist, firebrand) rather than moderate beliefs (see Table 4), which echoes the findings of the previous research on Muslims in general (e.g. Baker et al. 2013b, Moore et al. 2008, Samaie \& Malmir 2017).

Moderate collocates with Muslim 208 and 39 times in the AUS0206 and AUS1216 corpora respectively. An investigation of its concordance lines mostly 
reveals positive representations of Indonesian Muslims, such as condemning and combating terrorist attacks and respecting the rights of people of other religions. In a few instances, however, the use of the phrase moderate is problematised and employed in a scare quote:

... he [Hasyim Muzadi] declared that JI was part of a US strategy to "force Islam into a corner" and he called on the Indonesian and foreign governments to desist using the term. His statements on this matter are noteworthy because he is a well-known "moderate" Muslim. (Courier Mail, 20 October 2003)

(15) The baying crowds of people on the streets of Jakarta in the "moderate" Muslim country of Indonesia calling for the jailing of a Christian man who made an innocuous comment about the Koran and consequently has been hauled before a court on blasphemy charges merely confirms what many of us have long concluded. Our 21st-century secular society and culture has no place for Islam, moderate or otherwise. (The Australian, 'Letters/Ian Mastin', 15 December 2016)

In Example 14, the term moderate is utilised in scare quotes. Hasyim Muzadi is described as moderate but the term is used in scare quotes after he asserted that "JI was part of a US strategy to "force Islam into a corner"'. In the AUS0206 corpus, his statement is frequently cited since he is a leader of Nahdlatul Ulama, which is one of the largest moderate Islamic organisations in Indonesia. However, only in this case his moderation is questioned. This might be because the statement is considered misleading, not in accordance with the newspaper interests.

Example 15 is a letter to the editor from a reader, Ian Mastin. He commented on the blasphemy protests in Jakarta and questioned the moderation of Indonesian Muslims by using the term moderate in a scare quote. Also, he voiced a more extreme or controversial statement that "secular society and culture has no place for Islam, moderate or otherwise" and uses the case of the blasphemy protests to legitimate his claim. Since the editor can determine whether a letter written by members of the public can be published or not, it can be argued that publishing a letter containing negative representations of Muslims may be a legitimation strategy that the newspaper employs to print more controversial representations of Muslims, "in that the newspaper can distance itself from such opinions, whereas at the same time it can claim to give its readers a voice" (Baker et al. 2013b: 275).

Additionally, it is important to note that the phrase moderate Muslim largely occurs in discussions of terror attacks and extremism to juxtapose two stances. In other words, the construction of Indonesian Muslims as moderate mainly appears when the articles talk about issues of terrorism or fundamentalism: 
(16) Indonesia's Muslim population is overwhelmingly moderate but it has battled violent Islamic extremism from a small but virulent band of militants since the Bali bombings of 2002 that killed 202 people, including 88 Australians. (Sunday Age, 9 August 2015)

In this way, the radical decline of occurrences of the phrase in the 2012-2016 corpus might not be surprising since in this period topics about terrorism in the newspapers also decreased.

\begin{tabular}{|c|c|c|c|c|}
\hline Corpus & \multicolumn{2}{|l|}{ Extreme belief } & \multicolumn{2}{|c|}{ Moderate belief } \\
\hline \multirow{15}{*}{ AUS0206 } & radical & 233 & moderate & 208 \\
\hline & militant & 153 & secular & 32 \\
\hline & extremists & 135 & liberal & 21 \\
\hline & extremist & 81 & moderates & 13 \\
\hline & militants & 78 & tolerant & 9 \\
\hline & hardline & 63 & & \\
\hline & radicals & 46 & & \\
\hline & fundamentalist & 25 & & \\
\hline & fundamentalists & 24 & & \\
\hline & separatist & 20 & & \\
\hline & firebrand & 18 & & \\
\hline & hardliners & 16 & & \\
\hline & separatists & 15 & & \\
\hline & fanatics & 9 & & \\
\hline & total & 916 & & 283 \\
\hline \multirow{10}{*}{ AUS1216 } & \multicolumn{2}{|l|}{ extreme belief } & \multicolumn{2}{|c|}{ moderate belief } \\
\hline & hardliners & 21 & moderate & 39 \\
\hline & radical & 18 & secular & 9 \\
\hline & extremists & 15 & liberal & 6 \\
\hline & extremist & 13 & & \\
\hline & hardline & 11 & & \\
\hline & militants & 8 & & \\
\hline & radicals & 7 & & \\
\hline & separatist & 5 & & \\
\hline & total & 98 & & 54 \\
\hline
\end{tabular}

Table 4: Frequencies of belief word-collocates

Moving to the word devout and pious, devout collocates with Muslim in the AUS0206 and AUS1216 corpora, while pious only in the AUS0206 corpus. This type of belief seems to be located at the border between moderate and extreme 
beliefs. On the surface, it appears to suggest rather positive connotations or neutral stances. However, a concordance analysis of devout and pious in the AUS0206 indicates that Indonesian Muslims who are depicted as devout and pious tend to be connected to terrorism. In the AUS1216, nevertheless, a devout Indonesian Muslim is likely to be constructed more positively, such as refusing to leave a victim unattended, and taking the International Baccalaureate program.

Having considered representations of Indonesian Muslims as having either moderate or somewhere between extreme and moderate beliefs, I analysed the collocates suggesting extreme beliefs (firebrand, extremists, fundamentalists, hardliners) in the list. Firebrand collocates with Muslim in the AUS0206 corpus (18) and it is used to present Abu Bakar Bashir as a firebrand Muslim cleric. Hardliners collocates with Muslim in the AUS1216 (21), and Indonesian Muslim hardliners are constructed negatively, such as threatening to commit violence. This phrase mostly occurs in news about the blasphemy protest, a protest against a Lady Gaga concert and Miss World pageant (all of which are keywords in the 2012-2016 corpus). What might be notable is that the extreme belief words tend to be in the form of nouns (extremists, fundamentalist and hardliners), indicating that they have become the sum of their beliefs and serving to emphasise their difference from others (Baker et al. 2013a).

\section{Summary of findings and concluding remarks}

This study has attempted to investigate representations of Indonesian Muslims in the Australian newspapers in two different periods (2002-2006 and 2012-2016) by using a methodological synergy of corpus linguistics and CDA. Overall, it shows that dominant discourses around Indonesian Muslims in the Australian newspapers are related to terrorism and extremism and they have not undergone a shift over the last 15 years. It should be noted that some collocates in the later period, such as scholars (occurring 8 times), decent (6), and feminist (5), give more positive depictions. Yet, they are minorities. It then can be argued that the media representations of Muslims in Indonesia, a country that is not involved in major conflict and wars, are still primarily negative. An unforeseen consequence of such negative constructions is the negative stereotype of Indonesian Muslims and Islam, associating them with terrorism and radicalism. For example, a Lowy Institute report in 2006 showed that most Australians considered Indonesia as "a dangerous source of Islamic terrorism" (Cook 2006: 2). A more recent poll in 2013 also still demonstrated that 54 per cent of Australians believed that Indonesia is "a dangerous source of Islamic terrorism" (Oliver 2013: 13).

Furthermore, this study has made a contribution towards demonstrating the benefits of applying corpus linguistic approaches to conduct CDA research, 
and added to ongoing discussions of Muslim representations in the media. It also contributes to show that discourse is time-bound and therefore the findings of CDA research should not be generalized beyond the researched period. Nevertheless, it is worth reflecting on some limitations of this research. First, the corpora used in this study are only in the form of words or text-only format and lack of visual information. Discourses are also conveyed through images, colours, and layout and these elements seem to be important for the news text since they can influence the meanings of the content of the article. Thus, future studies may consider this multimodal perspective and employ multimodal corpora if possible (see Adolphs \& Carter 2013 for further reading). Also, this study did not consider political orientations of the newspapers or the distinction between leftand right-leaning newspapers, which is of interest to critical discourse analysts. Therefore, further research of political stance is worthy of analysis.

\section{Notes}

1 The asterisk signifies all forms of the term

\section{References}

Adolphs, S. and Carter, R. (2013) Spoken Corpus Linguistics: From Monomodal to Multimodal. London: Routledge.

Anthony, L. (2018) AntConc (3.4.4) [Computer Software]. Tokyo, Japan: Waseda University. Online document. Retrieved on 2 November 2018 from http://www. laurenceanthony.net/software.

Baker, P. (2006) Using Corpora in Discourse Analysis. London: Continuum.

Baker, P. (2014a) 'Bad wigs and screaming mimis: Using corpus-assisted techniques to carry out critical discourse analysis of the representation of trans people in the British press.' In: Hart, C. and Cap, P. (eds) Contemporary Critical Discourse Studies. London: Bloomsbury. 211-235.

Baker, P. (2014b) Using Corpora to Analyze Gender. London: Bloomsbury.

Baker, P. (2016) 'The shapes of collocation.' International Journal of Corpus Linguistics 21(2), 139-164.

Baker, P., Gabrielatos, C. and McEnery, T. (2013a) Discourse Analysis and Media Attitudes: The Representation of Islam in the British Press. Cambridge: Cambridge University Press.

Baker, P., Gabrielatos, C. and McEnery, T. (2013b) 'Sketching muslims: A corpus driven analysis of representations around the word 'Muslim' in the British press 1998-2009.' Applied Linguistics 34(3), 255-278.

Baker, P. and McEnery, T. (2015) 'Introduction.' In: Baker, P. and McEnery, T. (eds) Corpora and Discourse Studies: Integrating Discourse and Corpora. London: Palgrave Macmillan. 1-20.

Bednarek, M. and Caple, H. (2012) News Discourse. London: Continuum.

Brown, L. and Richards, B. (2016) 'Media representations of Islam in Britain: A sojourner perspective.' Journal of Muslim Minority Affairs 36(3), 350-363. 
Caldas-Coulthard, C. R. (2003) 'Cross-cultural representation of "Otherness" in media discourse.' In: Weiss, G. and Wodak, R. (eds) Critical Discourse Analysis: Theory and Interdisciplinarity. Basingstoke: Palgrave Macmillan. 34-46.

Cook, I. (2006) Australia, Indonesia and the World: Public Opinion and Foreign Policy. Online document. Retrieved on 7 December 2018 from https:/www.lowyinstitute. org/publications/lowy-institute-poll-2006-australia-indonesia-and-world.

Emmerson, D. K. (2002) 'Whose Eleventh? Indonesia and the United States since 11 September.' The Brown Journal of World Affairs 9(1), 115-126.

Fowler, R. (1991) Language in the News: Discourse and Ideology in the Press. Abingdon: Routledge.

Golding, P. and Elliott, P. R. C. (1979) Making the News. $1^{\text {st }}$ ed. London: Longman.

Grice, H. P. (1975) 'Logic and conversation.' In: Cole, P. and Morgan, J. L. (eds) Syntax and Semantics 3: Speech Acts. New York: Academic Press. 41-58.

Habermas, J. (1996) Between Facts and Norms: Contributions to a Discourse Theory of Law and Democracy. Cambridge, Mass.: MIT Press.

Hunston, S. (2002) Corpora in Applied Linguistics. Cambridge: Cambridge University Press.

Kabir, N. (2006) 'Representation of Islam and Muslims in the Australian media, 2001-2005.' Journal of Muslim Minority Affairs 26(3), 313-328.

Leech, G. N. (2014) The Pragmatics of Politeness. Oxford: Oxford University Press.

Louw, B. (1993) 'Irony in the text or insincerity in the writer? The diagnostic potential of semantic prosodies.' In: Baker, M., Francis, G., Tognini-Bonelli, E. and Sinclair, J. M. (eds) Text and Technology. Amsterdam: John Benjamins. 157-176.

Mackie, J. (2015) Australia and Indonesia: Current Problems Future Prospects. Lowy Institute for International Policy. Online document. Retrieved from https://www. lowyinstitute.org/publications/australia-and-indonesia-current-problems-futureprospects.

Magouirk, J., Atran, S. and Sageman, M. (2008) 'Connecting terrorist networks.' Studies in Conflict \& Terrorism 31(1), 1-16.

Mautner, G. (2007) 'Mining large corpora for social information: The case of elderly.' Language in Society 36(1), 51-72.

McEnery, T., McGlashan, M. and Love, R. (2015) 'Press and social media reaction to ideologically inspired murder: The case of Lee Rigby.' Discourse \& Communication 9(2), 237-259.

Moore, K., Mason, P. and Lewis, J. M. W. (2008) Images of Islam in the UK: The Representation of British Muslims in the National Print News Media 2000-2008. Cardiff School of Journalism, Media and Cultural Studies.

Oliver, A. (2013) Australia and the World: Public Opinion and Foreign Policy. Online document. Retrieved on 7 December 2018 from https://www.lowyinstitute.org/sites/ default/files/lowypoll2013_web_1_0.pdf.

Pavlova, E. (2007) 'From a counter-society to a counter-state movement: Jemaah Islamiyah according to PUPJI.' Studies in Conflict \& Terrorism 30(9), 777-800.

Reisigl, M. and Wodak, R. (2001) Discourse and Discrimination: Rhetorics of Racism and Antisemitism. London: Routledge.

Richardson, J. E. (2004) (Mis)Representing Islam: The Racism and Rhetoric of British Broadsheet Newspapers. Amsterdam: John Benjamins.

Samaie, M. and Malmir, B. (2017) 'US news media portrayal of Islam and Muslims: A corpus-assisted critical discourse analysis.' Educational Philosophy and Theory 49(14), 1351-1366. 
Smith, A. L. (2003) 'A glass half full: Indonesia-US relations in the age of terror.' Contemporary Southeast Asia: A Journal of International and Strategic Affairs 25(3), 449-472.

Stubbs, M. (2001) Words and Phrases: Corpus Studies of Lexical Semantics. London: Blackwell Publishers.

Stubbs, M. (2007) 'Quantitative data on multi-word sequences in English: The case of the word world.' In: Hoey, E. (ed.) Text, Discourse and Corpora: Theory and Analysis. London: Continuum. 163-189.

van Dijk, T. A. (1988) News Analysis: Case Studies of International and National News in the Press. Hillsdale, NJ: Erlbaum.

van Leeuwen, T. (2007) 'Legitimation in discourse and communication.' Discourse \& Communication 1(1), 91-112.

Wodak, R. and Meyer, M. (2016) 'Critical discourse analysis: History, agenda, theory.' In: Wodak, R. and Meyer, M. (eds) Methods of Critical Discourse Analysis. $3^{\text {rd }}$ ed. London: Sage. 1-22.

Muchamad Sholakhuddin Al Fajri is a lecturer in linguistics at Universitas Airlangga, Indonesia. His research interests include corpus linguistics, (critical) discourse analysis, language and media, and language and gender. $\mathrm{He}$ is also a member of editorial board and a reviewer in some national and international Indonesian linguistic journals.

Address: Muchamad Sholakhuddin Al Fajri, Fakultas Vokasi, Universitas Airlangga, Jl. Dharmawangsa Dalam Selatan No. 28-30, Airlangga, Kec. Gubeng, Kota SBY, Jawa Timur 60286, Indonesia. [e-mail: m-sholakhuddin-alfajri@vokasi.unair.ac.id] 